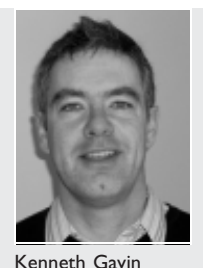

Kenneth Gavin Lecturer, School of Architecture, Landscape nd Civil Engineering, University College Dublin, Ireland

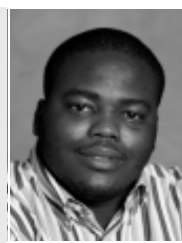

Abidemi Adekunte Senior Group Design Engineer, Van-elle Ltd; former Research Assistant, School of Architecture, Landscape and Civil Engineering Architecture, Landscape and Civil Engl

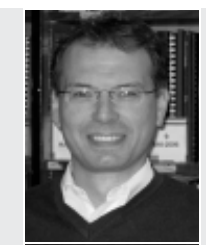

Brendan O'Kelly

Lecturer, Department of Civil, Structural and

Environmental Engineering, Trinity College

Dublin, Ireland

\title{
A field investigation of vertical footing response on sand
}

K. Gavin Phd, CEng, MIEl, A. Adekunte BE, CEng, MIEl and B. O’Kelly PhD, CEng, CEnv, MICE, FIEl, PGeo, MIGI, FGS

This paper presents the results from an experimental programme that studied the factors affecting the bearing resistance of shallow footings in sand. In particular, the tests considered the effects of the footing width and embedment depth on the pressuresettlement response. By comparing the results with field tests on full-scale footings, simple correlations between the bearing pressure mobilised at normalised settlement levels of $5 \%$ and $10 \%$ of the footing width and the cone penetration test $q_{c}$ value were studied. These correlations were found to be independent of footing size, embedment depth and sand state, although they were affected by creep. The rate of mobilisation of the footing resistance at low settlements was found to be strongly dependent on the initial soil state and the previous loading history. A simple non-linear elastic soil model was found to adequately predict this response.

\section{NOTATION}

$\boldsymbol{c}^{\prime}$ effective cohesion

$D \quad$ embedment depth

$D_{\mathrm{r}} \quad$ relative density

$D_{50} \quad$ mean grain size

$d_{\gamma}, d_{\mathrm{q}} \quad$ embedment depth correction factors

$\boldsymbol{E}_{0} \quad$ small-strain stiffness

$E_{\mathrm{S}}^{\prime} \quad$ equivalent linear-elastic secant modulus

$I_{\rho} \quad$ influence factor

$I_{\mathrm{R}} \quad$ rigidity ratio

$m \quad$ creep coefficient

$N_{\mathrm{c}}, N_{\gamma}, N_{\mathrm{q}} \quad$ bearing capacity factors

$\boldsymbol{p}_{\mathrm{p}} \quad$ PMT pressure measured at a cavity strain of $R$

$\boldsymbol{q}, \boldsymbol{q}_{\text {all }}, \boldsymbol{q}_{\text {ult }}$ bearing pressure, allowable bearing pressure and ultimate bearing resistance

$\boldsymbol{q}_{\mathrm{c}} \quad$ cone penetration test end resistance value

$\boldsymbol{q}_{0.05}, \boldsymbol{q}_{0.10}$ bearing resistances mobilised at normalised settlement of $s / B=5 \%$ and $10 \%$

$\Delta R \quad$ cavity strain measured in the pressuremeter text

$R_{0} \quad$ original radius of the pressuremeter cavity

$s, s_{\mathrm{c}} \quad$ footing settlement, creep settlement

$s_{\gamma}, S_{\mathrm{q}} \quad$ shape correction factors

$t$ time

$t_{\text {ref }} \quad$ reference time

$\alpha \quad$ empirical constant linking $\boldsymbol{q}$ and $\boldsymbol{q}_{\mathrm{c}}$

$\beta \quad$ ratio of $E_{\mathrm{s}}^{\prime} / \boldsymbol{q}_{\mathrm{c}}$

$\Gamma$
$\Gamma_{\text {Design }}$
$\Gamma_{\text {Mean }}$
$\gamma$
$v$
$\phi^{\prime}$

empirical function linking $q$ and $q$

design value is mean minus one standard

deviation

Mean value of $\Gamma$ from case histories

unit weight of the ground

Poisson's ratio

friction angle

\section{INTRODUCTION}

Routine design of shallow footings on sand is commonly performed using the conventional bearing capacity approach to calculate the ultimate bearing capacity $\boldsymbol{q}_{\text {ult }}$, given by

\begin{tabular}{|l|l|}
\hline ult & $=0.5 B \gamma N_{\gamma} s_{\gamma} d_{\gamma}+\boldsymbol{c}^{\prime} N_{\mathrm{c}} s_{\mathrm{c}}+\gamma D N_{\mathrm{q}} s_{\mathrm{q}} d_{\mathrm{q}}$ \\
\hline
\end{tabular}

in which $B$ is the footing width; $\gamma$ is the unit weight of the ground; $\boldsymbol{c}^{\prime}$ is the effective cohesion; $D$ is the embedment depth; $N_{\gamma}, N_{\mathrm{c}}$ and $N_{\mathrm{q}}$ are bearing capacity factors that depend on the footing shape and the effective friction angle $\phi^{\prime}$ of the soil; and factors $s_{\gamma}, s_{\mathrm{c}}, S_{\mathrm{q}}, d_{\gamma}$ and $d_{\mathrm{q}}$ take account of the footing shape and embedment depth.

In uncemented dry or saturated sand $\left(\boldsymbol{c}^{\prime}=0\right)$ the second term of Equation 1 reduces to zero, and the non-geometrical variables are the bearing capacity factors. As noted by Randolph et al., ${ }^{1}$ the accuracy with which the bearing capacity factors for a given soil can be determined has increased substantially in recent years, and the main uncertainty in the implementation of Equation 1 lies in the choice of an appropriate friction angle. The primary complication is the difficulty in sampling cohesionless soils to allow strength testing on representative specimens, and the stress-dependent effects on choice of friction angle. To overcome some of these challenges, greater reliance is being placed on in situ tests such as the standard penetration test (SPT) $N$ value, or the end resistance $\left(\boldsymbol{q}_{\mathrm{c}}\right)$ value measured in the cone penetration test (CPT).

A series of plate loading tests were undertaken in the present study to assess the effects of the footing width and embedment depth on the bearing resistance of model footings in dense sand. The tests were performed at a site where the sand had already been well characterised, primarily through the use of in situ tests. In particular, a number of CPTs had been performed in close proximity to the footing tests. The test results are 
compared with full-scale footing tests to study factors affecting empirical correlations between the measured CPT $\boldsymbol{q}_{\mathrm{c}}$ values and the bearing resistances mobilised at settlement levels typically associated with the serviceability limit state.

\section{BACKGROUND}

A number of researchers have noted that model footing tests should be corrected for scale effects. Such scale effects arise because of the dependence of the non-linear stress-strain response on the current stress level, ${ }^{2}$ and the ratio of the model width to the sand grain size. ${ }^{3}$ The bearing capacity equation (Equation 1) predicts that the ultimate bearing resistance will increase linearly with footing width and depth. Using model footings placed at the surface of sand, Cerato and Lutenegger ${ }^{4}$ showed clearly that the bearing capacity factor $N_{\gamma}$ reduced significantly as the footing width increased. (See also Yamamoto et al. ${ }^{5}$, White et $a l .{ }^{6}$ and Zhu et al. ${ }^{7}$ )

Briaud $^{8}$ compiled data from a number of footing tests performed in the field to investigate the effects of footing width and embedment depth on the bearing pressure mobilised by footings in sand. One case history originally reported by Ismael $^{9}$ included tests where both the footing width and the embedment depth were varied. These comprised two test series in an overconsolidated sand deposit, the first on a $0.5 \mathrm{~m}$ square footing (series 1 ) and the second on a larger, $1.0 \mathrm{~m}$ square footing (series 2). Both models were tested at four embedment depths $(D)$, varying from 0.5 to $2.0 \mathrm{~m}$ below ground level (bgl). The pressure-settlement curves for these tests are shown in Figure 1a. It is clear that, at a given displacement, the smaller footing (series 1) mobilised a much higher bearing stress. However, there was no consistent increase in bearing stress when the embedment depth increased from 0.5 to $2 \cdot 0 \mathrm{~m}$ in the overconsolidated sand deposit (in which the SPT $N$ values were relatively constant with depth). Briaud ${ }^{8}$ demonstrated that when the bearing pressure was normalised by the mean SPT $N$ value within the zone of influence of the footing, and the settlement was normalised by the footing width, the normalised pressure-settlement curves for the tests were unique (Figure 1b). Similar results were obtained from a range of sites where the bearing pressure had been normalised by in situ test data from the SPT, CPT and pre-bored pressuremeter test (PMT).

Approaches that directly link the allowable bearing pressure $\left(\boldsymbol{q}_{\text {all }}\right)$ mobilised at specified displacement levels with SPT $N$ values have been suggested by Terzaghi and Peck ${ }^{10}$ and Burland and Burbridge, ${ }^{11}$ among others. Empirical correlations that link the bearing resistance $(\boldsymbol{q})$ mobilised at some normalised displacement level $(s / B)$ with the $\boldsymbol{q}_{\mathrm{c}}$ value are typically of the form

\section{2}

$$
\boldsymbol{q}=\alpha \boldsymbol{q}_{\mathrm{c}}
$$

where $\alpha$ is an empirical constant, and $\boldsymbol{q}$ is the bearing pressure typically mobilised at settlement levels of $s / B=5 \%$ and $10 \%$ of the footing width (denoted by $\boldsymbol{q}_{0.05}$ and $\boldsymbol{q}_{0.10}$ respectively).

Eslaamizaad and Robertson ${ }^{12}$ compiled a database of footing tests, and suggested that $\alpha$ depends on the soil density and relative embedment $(D / B)$. Lee and Salgado ${ }^{13}$ reported finiteelement analyses (FEA) of footings on sand. They investigated

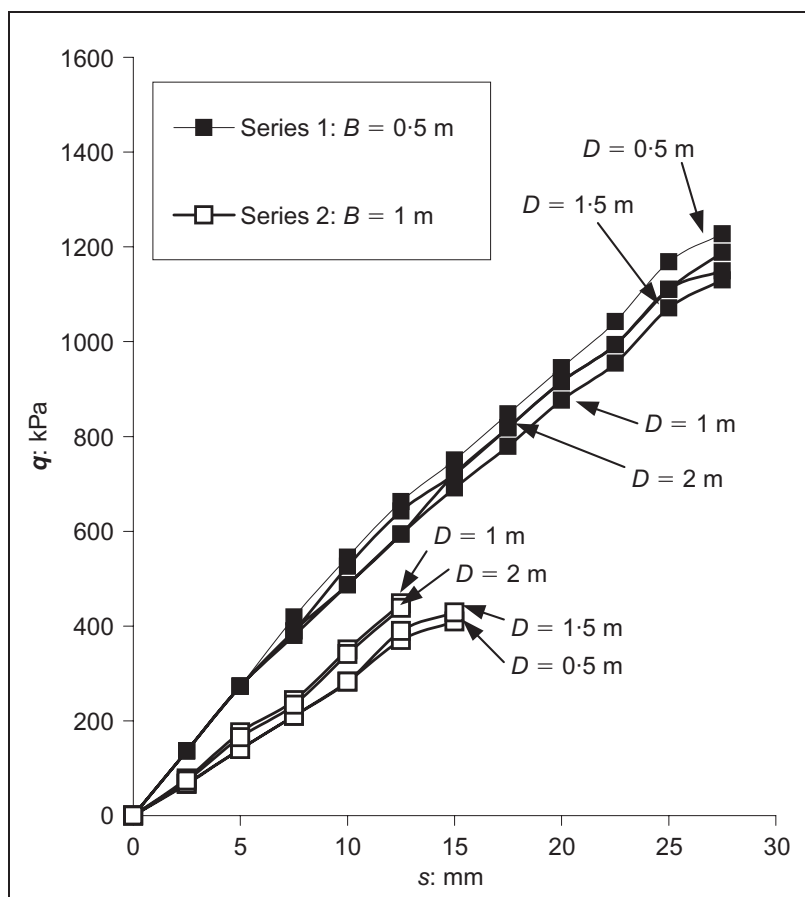

(a)

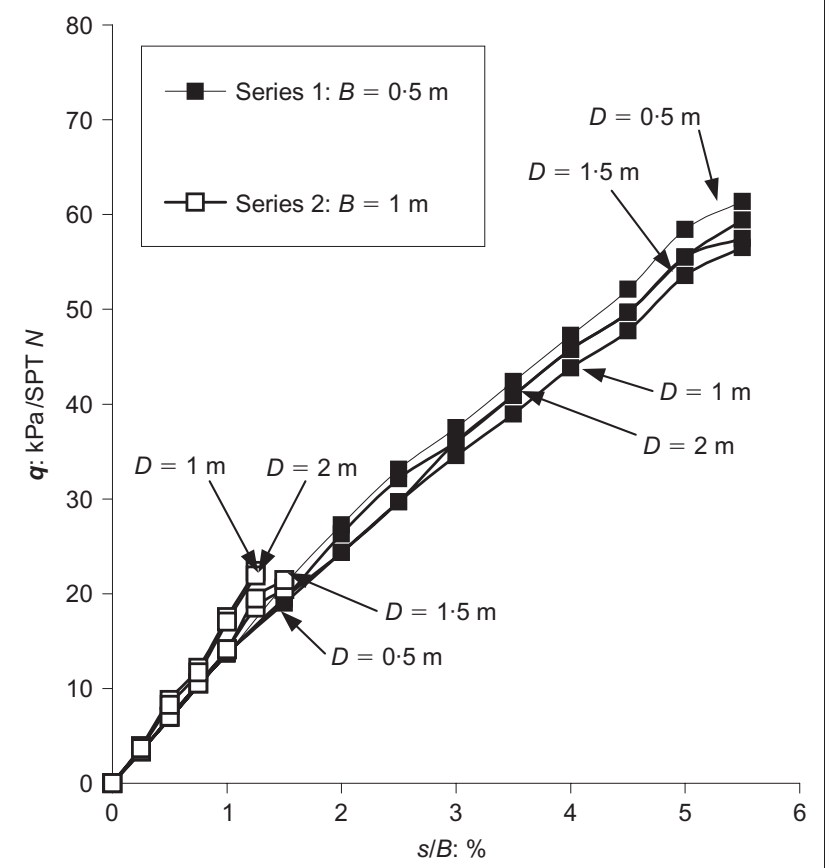

(b)

Figure I. Pressure-settlement curves from Kuwait:

(a) pressure-settlement response; (b) normalised pressuresettlement response

the effect of footing width and relative density $\left(D_{\mathrm{r}}\right)$ on the mobilised bearing resistance. Their data, shown in Figure 2 (for $s / B=10 \%$ ), show that $\alpha$ increased when the relative density of the soil reduced and the footing width increased. The rate at which $\alpha$ increased with the footing width depended on the relative density of the soil, with an increase of 35\% being noted for $D_{\mathrm{r}}=90 \%$ when the footing width increased from $1 \mathrm{~m}$ to $3 \mathrm{~m}$, whereas the increase was only $5 \%$ for $D_{\mathrm{r}}=30 \%$.

Randolph et al. ${ }^{1}$ summarised the results of laboratory and field tests and numerical analyses performed on shallow footings and buried piles. Although a relatively wide range of $\alpha$ values 


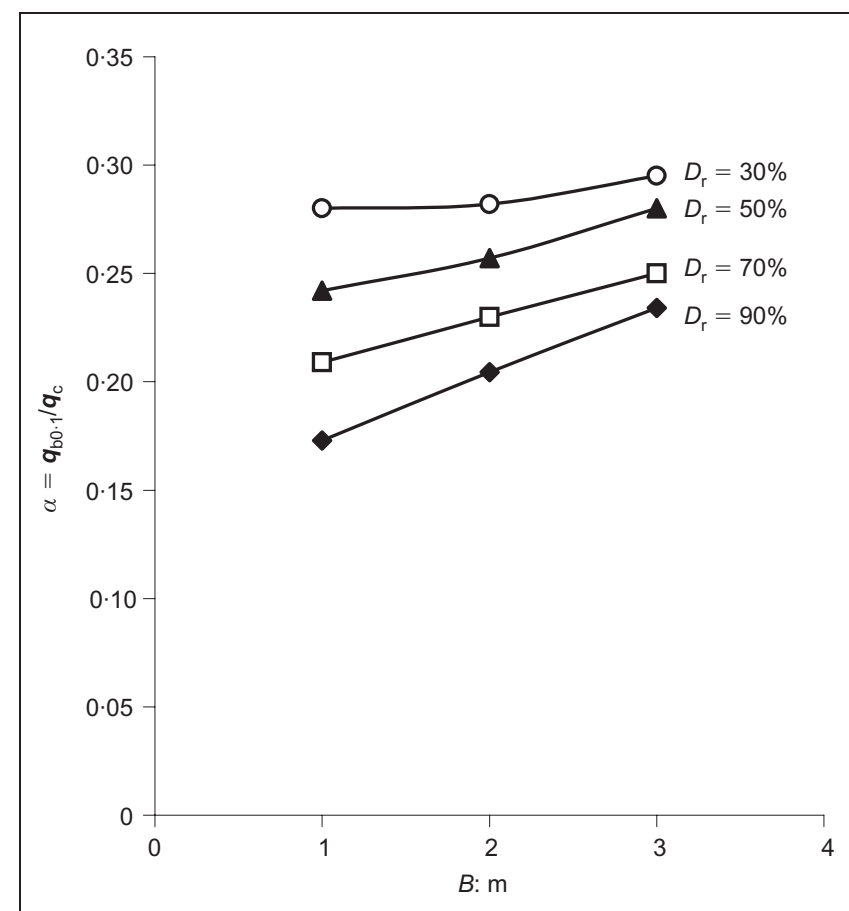

Figure 2. Effect of sand state and footing width on $\mathbf{q}_{0.10} / \mathbf{q}_{\mathrm{c}}{ }^{13}$

were reported, with $\alpha=0 \cdot 09-0 \cdot 16$ at $s / B=5 \%$, increasing to $\alpha=0 \cdot 13-0 \cdot 21$ at $s / B=10 \%$, there was no evidence that $\alpha$ varied with footing width or sand state. This is in keeping with observations from tests that measured the base resistance of full replacement bored piles by De Cock et al. ${ }^{14}$ and Cadogan and Gavin, ${ }^{15}$ who note that an $\alpha$ value of approximately $0 \cdot 2$ provides a good fit to the data available at $s / B=10 \%$.

However, it should be noted that the number of high-quality case studies of full-scale pile tests is limited, and the natural data scatter could obscure some fundamental trends identified in the FEA method.

Owing to the relatively large ultimate bearing resistance of sand, foundations are usually remote from failure. Hence the designer is primarily concerned with estimating the footing settlement when the safe or allowable bearing pressure $\left(\boldsymbol{q}_{\mathrm{all}}\right)$ is applied. This is typically achieved by assuming that over this stress range the foundation response can be predicted using an appropriate linear-elastic, secant Young's modulus $\left(E_{\mathrm{s}}^{\prime}\right)$, and a myriad of recommendations are available in the literature to assist in the choice of this parameter value. ${ }^{16}$

The settlement $s$ at a given applied pressure can be estimated using the standard equation for predicting the elastic settlement beneath a plate, ${ }^{17}$

\begin{tabular}{|l|l|}
\hline 3 & $s=\frac{\mathbf{q} B\left(1-v^{2}\right) I_{\rho}}{E_{\mathrm{s}}^{\prime}}$ \\
\hline
\end{tabular}

where $v$ is the Poisson's ratio value and $I_{\rho}$ is a settlement influence factor that depends on the footing shape and rigidity, the embedment depth, and the founding layer thickness. The principal difficulty with the application of Equation 3 concerns the selection of a representative $E_{\mathrm{s}}^{\prime}$ value. A number of researchers have proposed direct correlations between $E_{\mathrm{s}}^{\prime}$ and $\boldsymbol{q}_{\mathrm{c}}\left(E_{\mathrm{s}}^{\prime}=\beta \boldsymbol{q}_{\mathrm{c}}\right)$. While a wide range of $\beta$ values have been published, Das ${ }^{16}$ compiled values recommended by 13 researchers, who generally recommended $\beta$ values ranging from 1 to 3 . However, Lehane et al. ${ }^{18}$ and others have shown that at relatively small strain levels there is a weak dependence between $E_{\mathrm{s}}^{\prime}$ and $\boldsymbol{q}_{\mathrm{c}}$, with the effects of stress level and ageing being dominant, which suggests that constant $\beta$ values should be used with caution.

Briaud and Gibbens ${ }^{19}$ noted that the deformation pattern recorded by inclinometers installed beneath test footings resembled the barrelling effects caused by the inflation of a PMT device. Briaud ${ }^{5}$ proposed that the complete pressuresettlement response of a footing could be constructed from the pressuremeter expansion curve using the transformation

\begin{tabular}{|c|c|}
\hline $4 a$ & $\frac{S}{B}=0 \cdot 24 \frac{\Delta R}{R_{0}}$ \\
\hline $4 b$ & $\boldsymbol{q}=\Gamma \boldsymbol{p}_{\mathrm{p}}$ \\
\hline
\end{tabular}

where $\Delta R / R_{0}$ is the ratio of the change in radius during expansion to the original radius of the PMT cavity; $\boldsymbol{q}$ is the vertical stress mobilised when the footing settlement is $s ; \boldsymbol{p}_{\mathrm{p}}$ is the PMT pressure when the cavity expansion is $\Delta R$; and $\Gamma$ is the gamma function linking $\boldsymbol{p}_{\mathrm{p}}$ and $\boldsymbol{q}$. Briaud ${ }^{5}$ compiled experimental measurements and numerical estimates of $\Gamma$ (Figure 3) and proposed two best-fit $\Gamma$ functions: $\Gamma_{\text {Mean }}$ based on the mean data, and $\Gamma_{\text {Design }}$ based on the mean minus one standard deviation. It is noteworthy that there is considerable scatter in the $\Gamma$ data in Figure 3, particularly at strain levels $(s / B)$ below $2 \%$, and Briaud ${ }^{5}$ noted that this scatter suggests the likely error involved in the application of the $\Gamma$ functions. However, this effect may also be explained by the poor correlation between $E_{\mathrm{s}}^{\prime}$ at low strain levels and in situ test

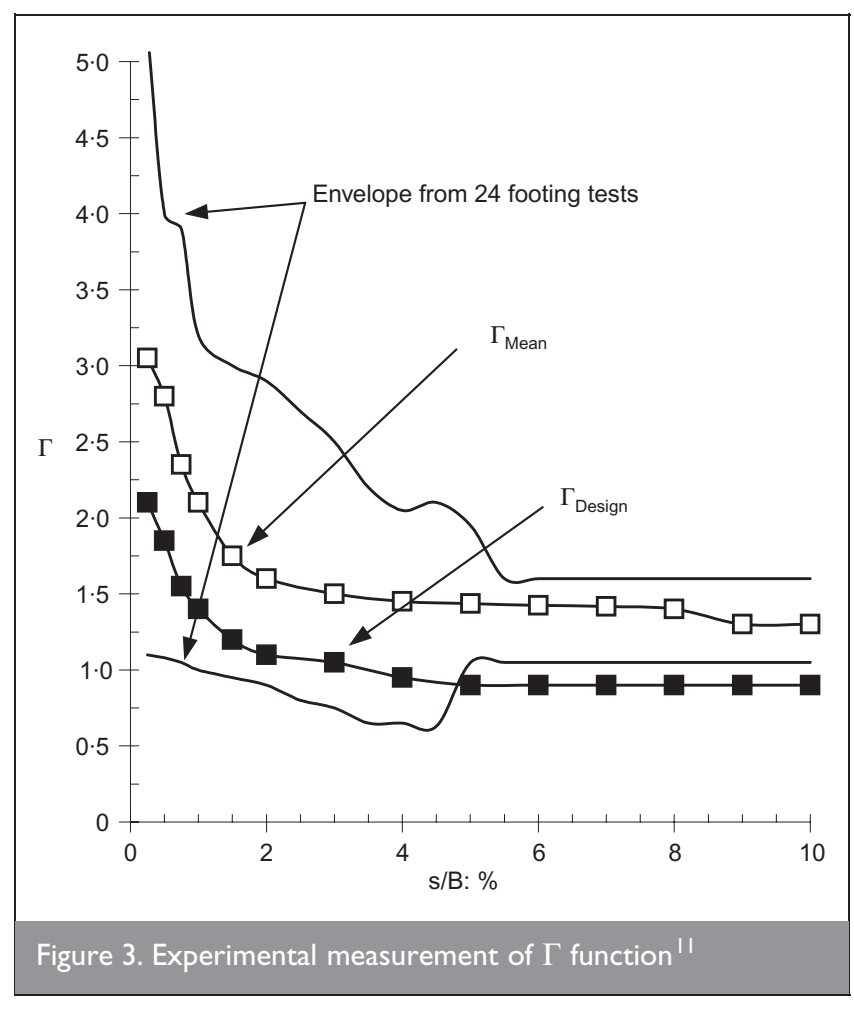


parameters (such as $\boldsymbol{q}_{\mathrm{c}}, N$ and $\boldsymbol{p}_{\mathrm{p}}$ ) measured in tests that impose large strains on the ground.

\section{DESCRIPTION OF EXPERIMENTS}

\section{I. Site conditions}

The plate load tests were performed at a sand quarry on the outskirts of Blessington village, located $25 \mathrm{~km}$ south-west of Dublin city. The sand, which was horizontally bedded, had been deposited at the base of a glacial lake. The particle grading between the beds varied from that of silty sand (mean grain size $\left.D_{50}=0.10 \mathrm{~mm}\right)$ to that of coarse sand $\left(D_{50}=\right.$ $0.32 \mathrm{~mm}$ ), depending on the level of the glacial lake at the time of deposition. Glacial action and the recent removal by quarrying of the upper $15 \mathrm{~m}$ of overburden material has resulted in the sand being in a heavily overconsolidated state.

The footing tests were performed at two locations at the site. The first test series was conducted in 2004 on $100 \mathrm{~mm}$ and $250 \mathrm{~mm}$ wide plates in an area of the quarry that had experienced no sand extraction for a number of years. The second test series was conducted in 2005 on $400 \mathrm{~mm}$ wide footings shortly after sand had been excavated to a depth of $2 \cdot 0 \mathrm{~m}$ below the 2004 test level. Four CPTs were performed at the test area in 2004 and repeated in 2005 (Figure 4a). The CPT $\boldsymbol{q}_{\mathrm{c}}$ traces were reasonably consistent, allowing the mean $\boldsymbol{q}_{\mathrm{c}}$ profiles (heavy traces in Figure 4a) to be used as representative profiles. The mean CPT profile for the first test series indicated very high $\boldsymbol{q}_{\mathrm{c}}$ values, typically about $20 \mathrm{MPa}$, at about $0.2 \mathrm{~m}$ bgl, gradually reducing to about $1.0 \mathrm{~m} \mathrm{bgl} \mathrm{(below} \mathrm{ground}$ level), and thereafter remaining relatively uniform (with $\boldsymbol{q}_{\mathrm{c}}=$ 15-18 MPa). The subsequent removal of the uppermost $2 \cdot 0 \mathrm{~m}$ depth of sand over the second test area in 2005 clearly had an effect on the near-surface CPT profile, with the CPT $\boldsymbol{q}_{\mathrm{c}}$ values gradually increasing with depth to about $1.0 \mathrm{~m}$ below the new reduced ground level, before again becoming relatively uniform at greater depth. Sand replacement tests indicated that the material is very dense (values of relative density of about $100 \%$ were recorded), and the groundwater table was located at about $5.0 \mathrm{~m}$ bgl (relative to the 2004 ground level). Seasonal variations of the natural water content were insignificant, with values of $6-7 \%$ being consistently measured for the sand above the groundwater table. The small-strain stiffness $\left(\boldsymbol{E}_{0}\right)$ profile was measured in situ at the 2004 ground level using the multichannel analysis of surface waves (MASW) technique and assuming a Poisson's ratio value of $0 \cdot 1$ at low strain levels (Figure $4 \mathrm{~b}$ ). The ratio of $\boldsymbol{E}_{0} / \boldsymbol{q}_{\mathrm{c}}$ measured at the site was approximately 11. Further details of the soil conditions at the test site have been reported by Gavin and 0'Kelly. ${ }^{20}$

\subsection{Experimental procedure}

The test plates were square steel plates, $25 \mathrm{~mm}$ thick, with side widths $B=100,250$ and $400 \mathrm{~mm}$. The footings were placed at the base of trenches that had been excavated such that $D / B$ ranged from 0.4 to $2 \cdot 0$. The load tests on the 100 and $250 \mathrm{~mm}$ footings were performed in 2004; the $400 \mathrm{~mm}$ footings were load-tested in 2005, shortly after the excavation of the $2 \mathrm{~m}$ depth of sand. The footings were vertically loaded using a $200 \mathrm{kN}$ truck for reaction. The load was typically applied in 5-10\% increments of the assumed capacity, and each increment was held for approximately $10 \mathrm{~min}$. The load was measured using a $200 \mathrm{kN}$ load cell. The vertical settlements of

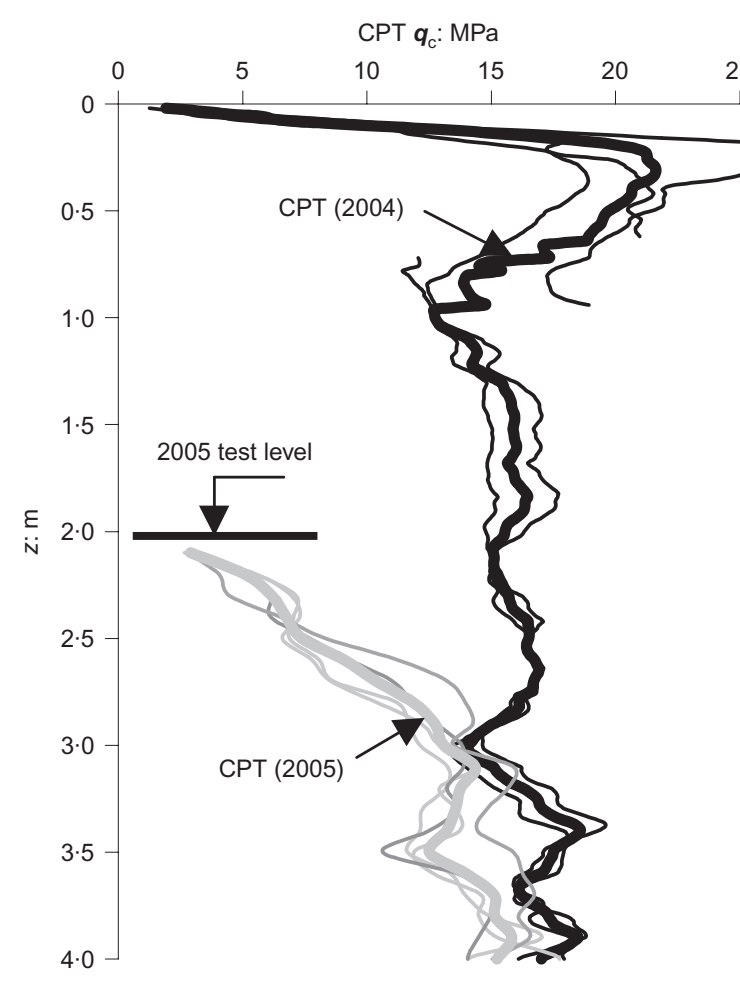

(a)

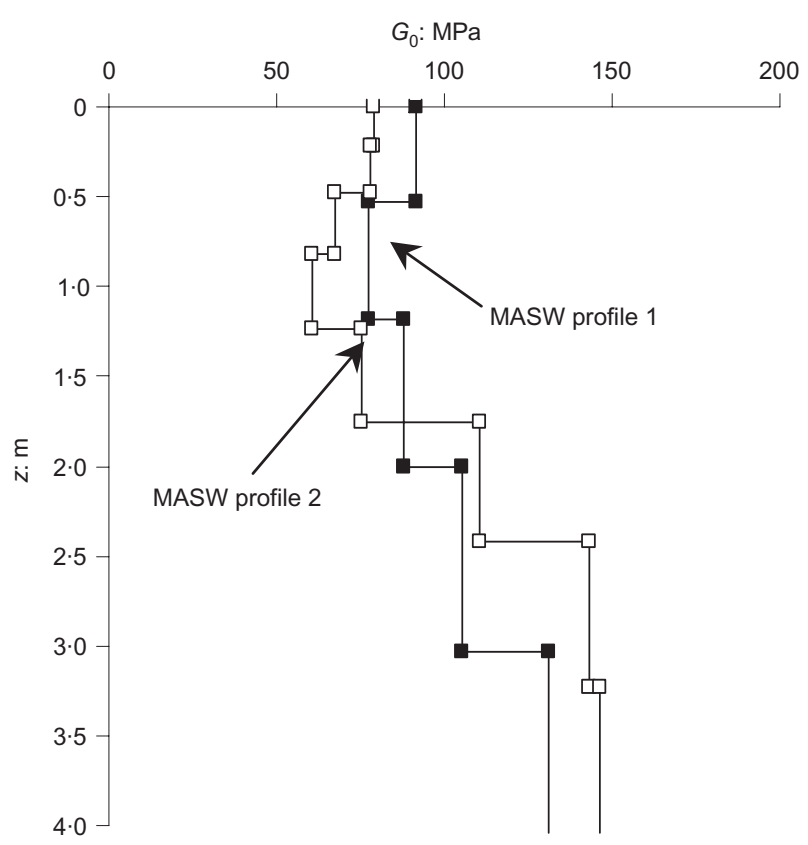

(b)

Figure 4. Characterisation of the Blessington site: (a) CPT $q_{c}$ end resistance against depth traces for the test area;

(b) small-strain stiffness profile for the 2004 test area

the footing corners were measured using four linearly variable displacement transducers (LVDTs) that were secured to a $4.0 \mathrm{~m}$ long reference beam. The load cell and the LVDTs were connected to a data-logger that recorded the load-settlement responses at $1 \mathrm{~s}$ intervals throughout the tests.

\subsection{Experimental results: pressure-settlement response of model footing tests}

The mobilisation of the bearing resistance $\boldsymbol{q}$ for the 100, 250 and $400 \mathrm{~mm}$ square plates with increasing settlement is shown 
in Figure 5a. Note that the settlement shown is the mean value of the four LVDT readings. The following trends emerge.

(a) The bearing pressures mobilised at relatively modest displacements were high, ranging from $\boldsymbol{q} \approx 1200 \mathrm{kPa}$ at $s=13 \mathrm{~mm}$ for the $400 \mathrm{~mm}$ plate to $\boldsymbol{q} \approx 2950 \mathrm{kPa}$ at $s=$ $21 \mathrm{~mm}$ for the $250 \mathrm{~mm}$ plate. The soft response of the $400 \mathrm{~mm}$ plates was measured in the area where recent removal of overburden had caused a significant decrease in the measured $\boldsymbol{q}_{\mathrm{c}}$ value.

(b) The plate size has a clear effect on the bearing resistance mobilised for a given settlement. For example, the bearing resistance mobilised at $s=5 \mathrm{~mm}$ increased from about $650 \mathrm{kPa}$ for the $400 \mathrm{~mm}$ plate to about $2600 \mathrm{kPa}$ for the $100 \mathrm{~mm}$ plate.

(c) The responses of bearing resistance against settlement for

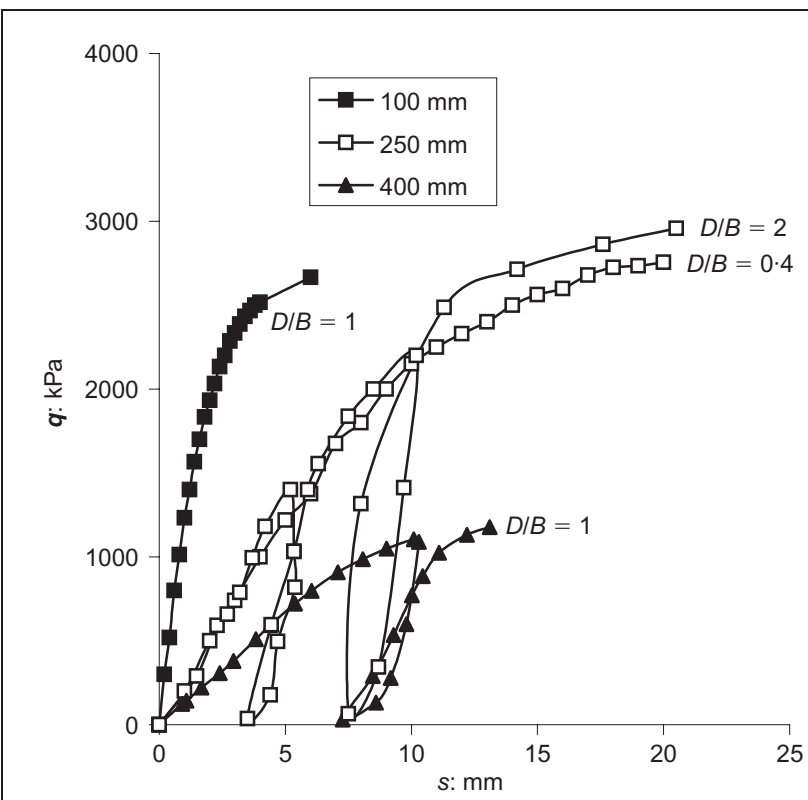

(a)

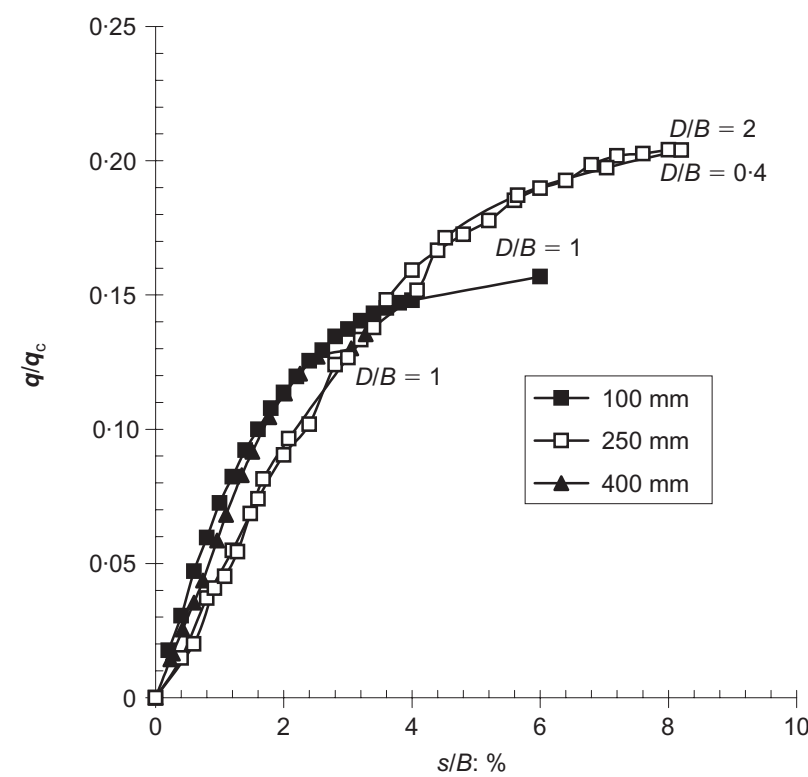

(b)

Figure 5. Effect of footing size on bearing resistances at Blessington site: (a) pressure-settlement response; (b) normalised pressure-settlement response all of the footings exhibit an initial near-linear phase, which extends to higher displacements for larger footings.

(d) When the 250 and $400 \mathrm{~mm}$ square plates were unloaded, the response during subsequent reloading was significantly stiffer than that experienced during the initial loading, and remained so until the bearing pressure had approached the previous maximum applied pressure $\left(\boldsymbol{q}_{\text {pre }}\right)$.

(e) Increasing the $D / B$ ratio from 0.4 to $2 \cdot 0$ for the $250 \mathrm{~mm}$ square plate did not appear to increase the bearing pressure mobilised by the footing significantly.

The data are replotted (ignoring reloading phases) in Figure 5b, in which the bearing pressure has been normalised by the CPT $\boldsymbol{q}_{\mathrm{c}}$ resistance (measured below the plate and averaged over a distance equal to $B(m)^{0.75}$ ), and the settlement has been normalised by the plate width. The data support the findings of Briaud, ${ }^{5}$ and suggest that the plate width and relative depth have no significant effect on the mobilised bearing resistance, provided that an appropriate measure of the soil strength (in this case the $\boldsymbol{q}_{\mathrm{c}}$ value) is used to normalise the bearing pressure.

\section{COMPARISON WITH OTHER DATA}

\section{I. Comparison of normalised bearing resistance of model and full-scale footings}

In order to examine possible scale effects, comparisons were made between the Blessington plate test results and 14 largescale footing tests from three sites where complete pressuresettlement curves had been published (Table 1). The field data included five tests performed at Texas A\&tM University (site A) on footings founded at $0.75 \mathrm{~m} \mathrm{bgl}$ and reported by Briaud and

\begin{tabular}{|lcccc|}
\hline Test site & $\begin{array}{c}\text { Width: } \\
\mathrm{m}\end{array}$ & $\begin{array}{c}\text { Depth: } \\
\mathrm{m}\end{array}$ & $\begin{array}{c}\mathrm{CPT} \\
\mathbf{q}_{\mathrm{c}}: \mathrm{kPa}\end{array}$ & SPT $\mathrm{N}_{60}{ }^{*}$ \\
\hline \multirow{3}{*}{ A Texas } & 1.0 & 0.75 & 7250 & 18 \\
& 1.5 & 0.75 & 6500 & 18 \\
& 2.5 & 0.75 & 6400 & 18 \\
& 3.0 & 0.75 & 7250 & 18 \\
& 3.0 & 0.75 & 5000 & 18 \\
B Kuwait & 0.5 & 0.5 & $7275 \dagger$ & 20 \\
& 0.5 & 1.0 & $7275 \dagger$ & 20 \\
& 0.5 & 1.5 & $7275 \dagger$ & 20 \\
& 0.5 & 2.0 & $7275 \dagger$ & 20 \\
& 1.0 & 0.5 & $7275 \dagger$ & 20 \\
& 1.0 & 1.0 & $7275 \dagger$ & 20 \\
& 1.0 & 1.5 & $7275 \dagger$ & 20 \\
C Shenton Park & 1.0 & 2.0 & $7275 \dagger$ & 20 \\
& 0.75 & 1.0 & 3800 & - \\
& 1.0 & 1.0 & 4080 & \\
& 1.0 & 0.5 & 3330 & \\
D Blessington & 1.5 & 1.0 & 4350 & \\
& 0.10 & 0.1 & 17000 & - \\
& 0.25 & 0.1 & 14500 & - \\
& 0.25 & 0.5 & 14500 & - \\
& 0.40 & 0.4 & 8700 & - \\
\hline
\end{tabular}

* SPT $N$ values have been corrected for energy effects. †CPT $\boldsymbol{q}_{\mathrm{c}}$ value from correlation with SPT $N$.

SPT $N$ and CPT $\boldsymbol{q}_{\mathrm{c}}$ values are estimated over the depth of influence equal to $B^{0.75}$ below the footing.

Table I. Details of model and full-scale load tests on square footings 
Gibbens. ${ }^{19}$ The medium-dense sand was in a lightly overconsolidated state $(O C R \approx 2$ ) following the removal of about $1.0 \mathrm{~m}$ overburden depth. The mean CPT $\boldsymbol{q}_{\mathrm{c}}$ resistance ranged from 5 to $7 \cdot 25 \mathrm{MPa}$ in the zone of influence of the footing.

The normalised pressure-settlement responses shown in Figure 6a suggest that a relatively unique curve, independent of the footing width, is obtained at a given strain level, which agrees

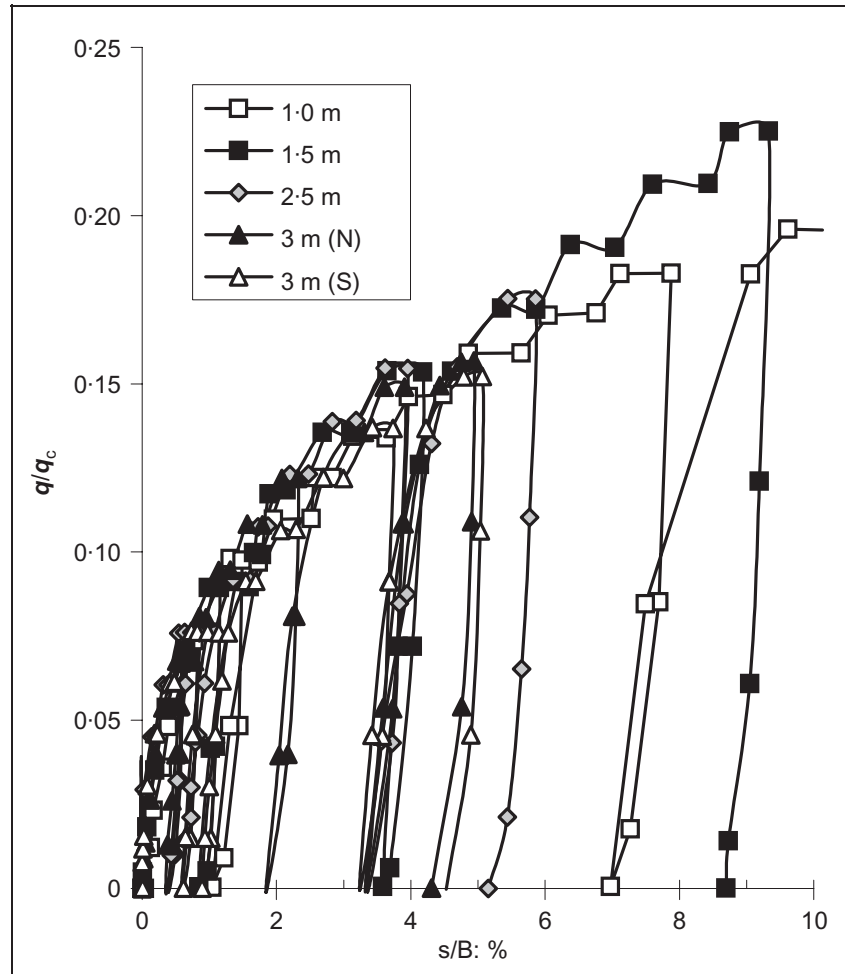

(a)

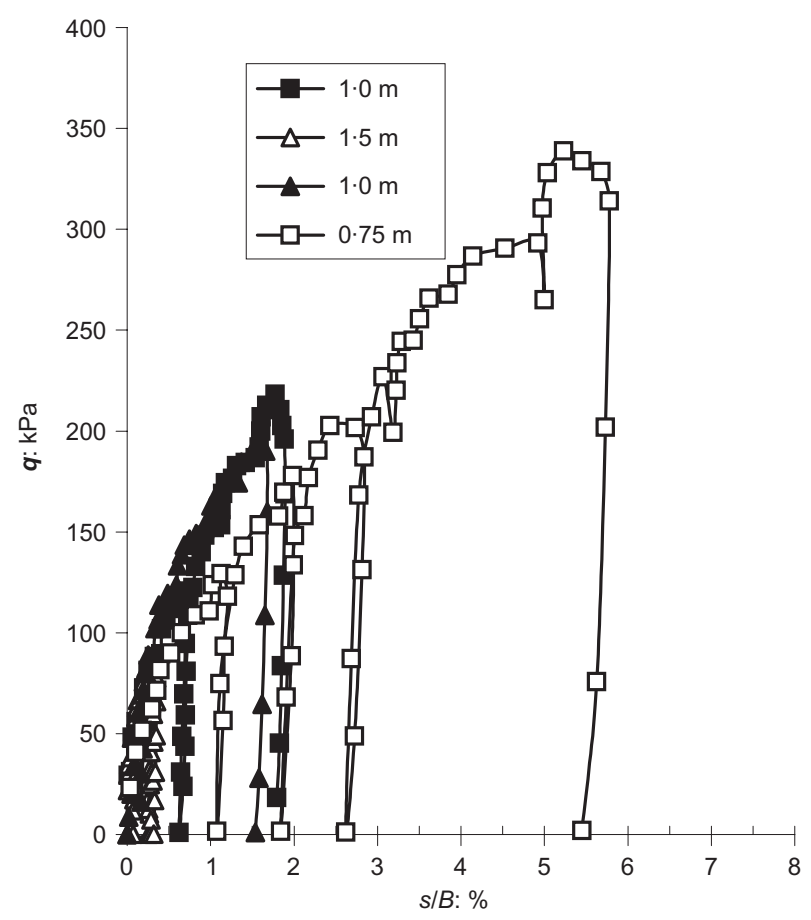

(b)

Figure 6. Pressure-settlement curves from footings tests in Table I: (a) Texas, Site A; (b) Shenton-Park, Site C with the findings of Briaud. ${ }^{5} \mathrm{~A}$ feature of the footing tests not noted at the Blessington site was the effect of creep (settlement at constant applied stress). The load test procedure at Texas involved maintaining each load increment for $30 \mathrm{~min}$ and occasionally for $24 \mathrm{~h}$. Creep-induced settlements are obvious from the test data, with the effect increasing at higher stress levels. Briaud and Gibbens ${ }^{19}$ showed that the creep settlement $\left(s_{\mathrm{c}}\right)$ response could be predicted using the equation

\begin{tabular}{|l|l|}
\hline 5 & $\frac{s_{\mathrm{c} 1}}{s_{\mathrm{c} 2}}=\left(\frac{t_{1}}{t_{2}}\right)^{n}$ \\
\hline
\end{tabular}

where $s_{\mathrm{c} 1}$ and $s_{\mathrm{c} 2}$ are the settlements after time periods $t_{1}$ and $t_{2}$ respectively, and $n$ is a creep exponent, with $n$ varying from 0.005 to 0.03 for sand at working stress levels.

An obvious consequence of the observed creep response is that the normalised pressure-settlement curve measured from a load test at the site is not unique, but rather depends on the load test procedure (i.e. the duration of the maintained load stage).

Ismael $^{9}$ reported eight footing tests performed in an overconsolidated silty sand at a site in Kuwait with the groundwater table located at $2.8 \mathrm{~m}$ bgl. No creep effects are evident in the published pressure-settlement response of these footings (shown in Figure 1). In situ testing yielded SPT $N$ values, and CPT $\boldsymbol{q}_{\mathrm{c}}$ values have been derived for the site using the correlation proposed by Kulhawy and Mayne. ${ }^{21}$

Lehane et al. ${ }^{18}$ reported four footing tests performed at the University of Western Australia geotechnical test site at Shenton Park, Perth. The tests were designed to investigate the effects of footing width and embedment depth on the footing response. The average CPT $\boldsymbol{q}_{\mathrm{c}}$ resistance varied from $3 \cdot 3 \mathrm{MPa}$ to $4 \cdot 3 \mathrm{MPa}$ within the zone of influence of the footings. The groundwater table was located at the base of the sand layer at about $5.5 \mathrm{~m}$ bgl. The normalised pressure-settlement response (see Figure 6b) was found to be independent of the footing width and embedment depth. Each step in the applied load during the testing was followed by a maintained load stage of 10 min duration. Significant creep settlement $\left(s_{\mathrm{c}}\right)$ occurred, even at relatively low stress levels, during the maintained load stages. Lehane et al. ${ }^{18}$ also noted that $s_{\mathrm{c}}$ increased in value with the natural logarithm of elapsed time $t$ since application of the load, and also with the natural logarithm of the creep rate. The following equations to model the creep response were proposed.

$$
6 \mathrm{a} \quad \frac{s_{\mathrm{c}}}{B}=m \ln \frac{t}{t_{\mathrm{ref}}} \Rightarrow \frac{\mathrm{d}\left(s_{\mathrm{c}} / B\right)}{\mathrm{d} t}=S_{\mathrm{n}}=\frac{m}{t}
$$

$6 \mathrm{~b} \quad \frac{S_{\mathrm{c}}}{B}=m \ln \frac{S_{\mathrm{nref}}}{S_{\mathrm{n}}}$


where $m$ is a creep coefficient and $t_{\text {ref }}$ is a reference time corresponding to the onset of the creep settlement.

Lehane et al. ${ }^{18}$ derived values for the creep coefficient $m$ from measurements of the one-dimensional creep settlement response of the footings, and the shear-induced creep measured in pressuremeter tests, over a range of various stress levels $\left(\boldsymbol{q} / \boldsymbol{q}_{\mathrm{ult}}\right)$ at the Shenton Park site, where $\boldsymbol{q}_{\mathrm{ult}}$ was obtained by extrapolating the measured pressure-settlement curves. The estimated $\boldsymbol{q}_{\mathrm{ult}}$ values ranged from 600 to $690 \mathrm{kPa}$ (which equated to $\boldsymbol{q}_{\mathrm{ult}} / \boldsymbol{q}_{\mathrm{c}}$ values of $0 \cdot 17-0 \cdot 19 \boldsymbol{q}_{\mathrm{c}}$ ), and the following best-fit expression was derived to describe the creep settlement response.

\begin{tabular}{|l|l|}
\hline 7 & $m=0.02\left(\frac{\boldsymbol{q}}{\boldsymbol{q}_{\mathrm{ult}}}\right)^{2}$ \\
\hline
\end{tabular}

\subsection{Normalised bearing resistance}

Figure 7a shows the normalised bearing resistances mobilised during all the model and full-scale load tests listed in Table 1. The mean CPT $\boldsymbol{q}_{\mathrm{c}}$ values recorded over a depth of $B(m)^{0.75}$ below the footing level were used in normalising the data. Although unload-reload tests were performed in all of the Texas A\&tM tests (site A), at Shenton Park (site C) and in some of the Blessington tests (site D), the unload-reload portions are not included in Figure 7a for clarity. Instead the overall pressure-settlement curves $^{5}$ are shown in Figure 7a. Creep significantly affected the footing response at two sites, Texas and Shenton Park (sites A and C respectively), with the effects becoming more pronounced at higher stress levels.

Withstanding the influence of creep, Figure 7a shows the following.

(a) At low strain levels $(s / B<4 \%)$, the pressure-settlement curves for each site appeared to be distinct, although the curves tend to converge at $s / B$ values greater than $4 \%$ (excluding Shenton Park, where creep effects were largest).

(b) The $\boldsymbol{q} / \boldsymbol{q}_{\mathrm{c}}$ values at larger strain show no tendency to vary with footing width or sand state, which suggests that, in the absence of significant creep, the bearing resistance at $s / B=5 \%$ can be conservatively estimated using $\alpha=0 \cdot 15$.

(c) While there is a dearth of data at larger normalised settlements, an $\alpha$ value of $0 \cdot 2$ (as recommended by Randolph et al., ${ }^{1}$ among others) appears reasonable, particularly for the sites where creep effects were insignificant. This value for $\alpha$ is seen to provide a reasonably conservative estimate of the bearing resistance mobilised over a range of footing size and sand state in the FEA analyses reported by Lee and Salgado ${ }^{13}$ (Figure 2).

Since the rate at which the normalised resistance develops during the early loading portion of the tests appears to be quite distinct for each site, the data are replotted at a reduced scale in Figure $7 \mathrm{~b}$. The bearing pressure is seen to mobilise more rapidly during the early stages of the footing tests performed at sites A and C (Texas and Shenton Park respectively) than at site B (Kuwait). The Blessington pressure-settlement curves (site D) exhibited an intermediate response. Although there is limited published information in the literature from footing tests presenting both the complete pressure-settlement curve and in

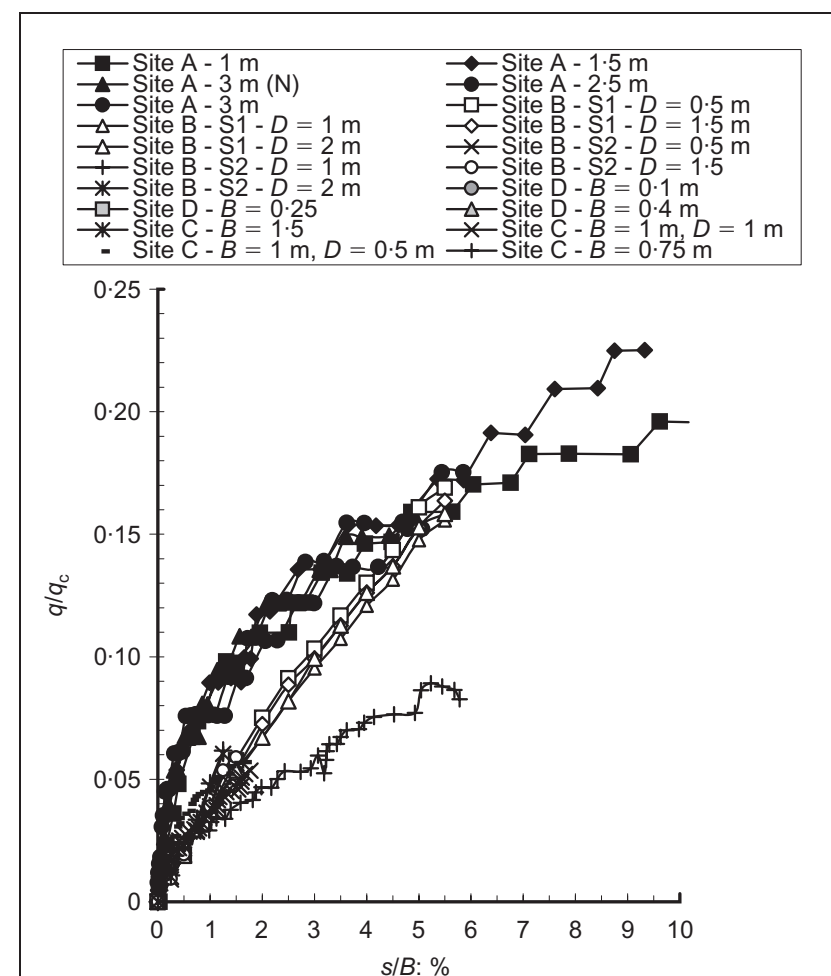

(a)
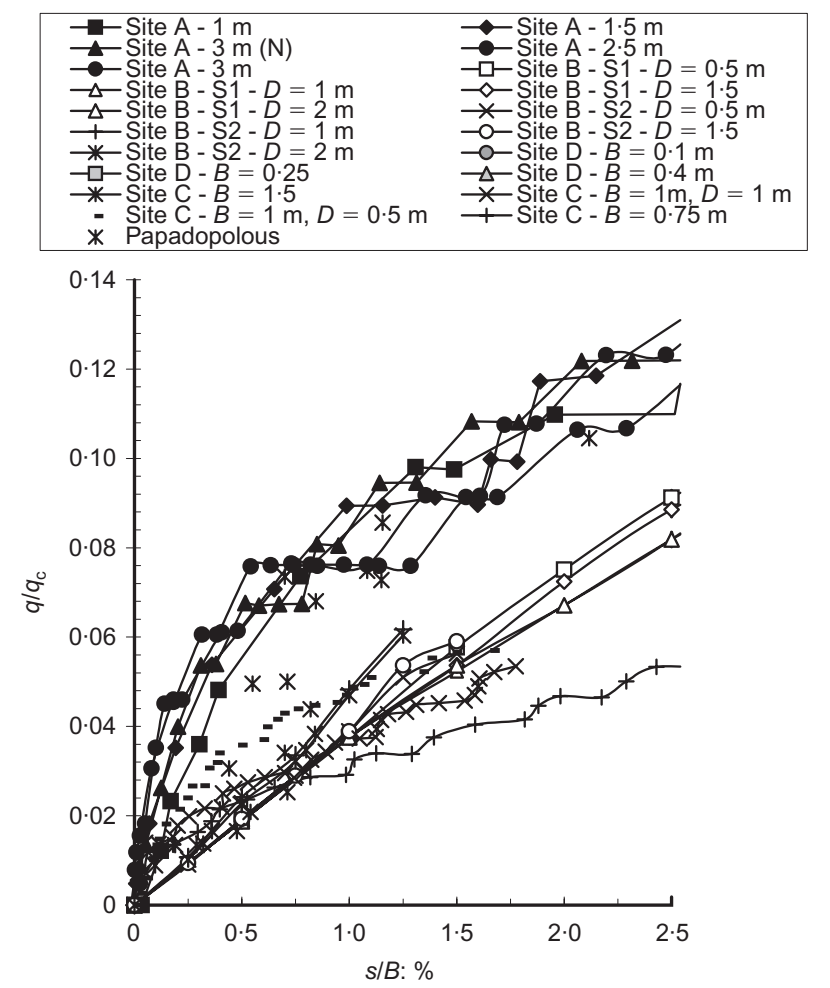

(b)

Figure 7. Normalised pressure-settlement response at all test sites: (a) normalised pressure settlement response at all sites; (b) normalised pressure settlement at low strain level

situ test results, Papadopulous ${ }^{22}$ compiled a database of settlement at working load and corresponding CPT $\boldsymbol{q}_{\mathrm{c}}$ values from 23 sites where the footing width ranged from $0.5 \mathrm{~m}$ to $36 \mathrm{~m}$. The data (shown as discrete points in Figure 7b) suggest that the pressure-settlement curves represent a reasonable envelope to field response. Interestingly, while the settlements 
measured under the footings in his database ranged between $3 \mathrm{~mm}$ and $21 \mathrm{~mm}$, the vast majority of footings in service settled by less than $1.25 \%$ of the footing width.

\subsection{Comparison of the stiffness response of footing tests} Pressure-settlement curves compiled from the different sources suggest that at large strains $(s / B>4 \%)$, and in the absence of significant creep, the $\boldsymbol{q} / \boldsymbol{q}_{\mathrm{c}}$ ratio was similar for the range of footing widths, embedment depths and sand states considered. However, a wide variation in the rate at which the bearing resistance was mobilised at strain levels of concern to foundation designers $(s / B<2 \cdot 5 \%)$ was evident. Although the curves for a given site were relatively uniform, irrespective of the range of footing sizes and depths considered, the overall response at the different sites was quite distinct.

The marked difference in the initial stiffness response (seen in Figure $7 b$ ) can be examined by considering the non-linear stiffness response of the sand. Figure 8a shows the equivalent linear-elastic secant modulus values ( $E_{\mathrm{s}}^{\prime}$ ) derived from the pressure-settlement curves using the standard equation for

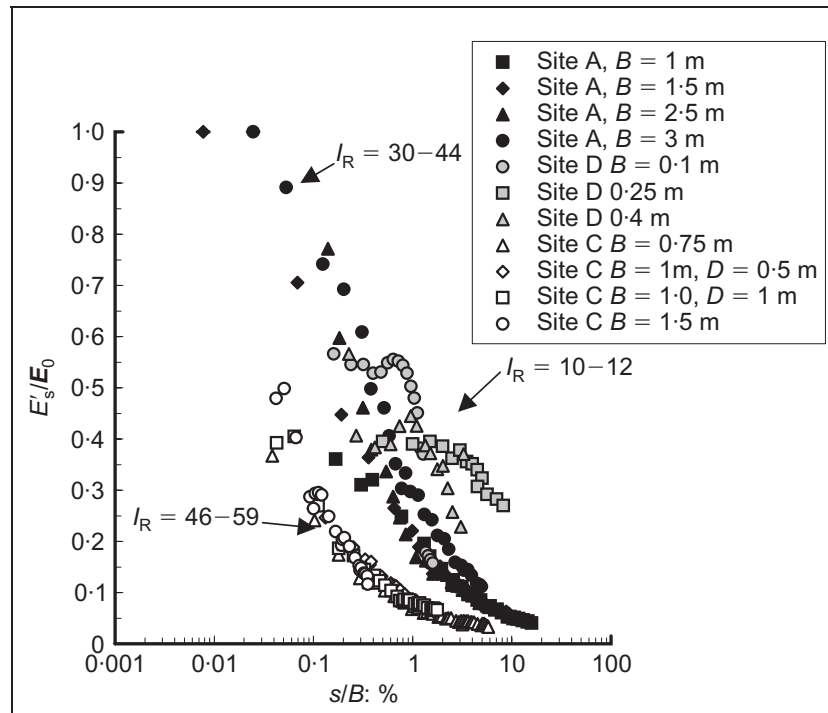

(a)

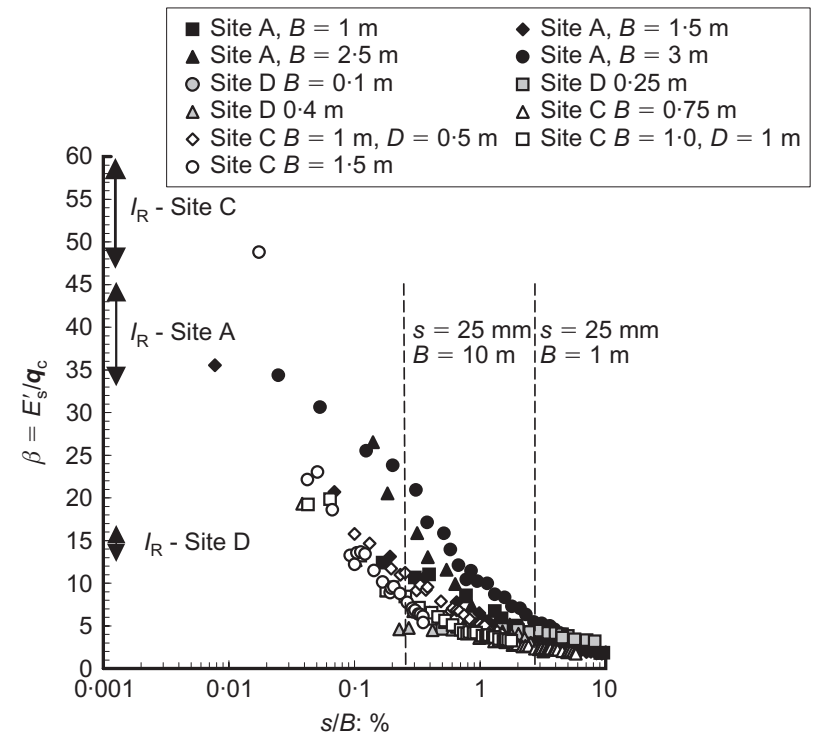

(b)

Figure 8. (a) Stiffness degradation curves for footing tests; (b) normalised stiffness degradation curves for footing tests predicting the elastic settlement beneath a plate (Equation 3), which were normalised by the small-strain stiffness (at sites A, $\mathrm{D}$ and $\mathrm{C}$ where $\boldsymbol{E}_{0}$ was measured). The normalised stiffness $\left(E_{s}^{\prime} / \boldsymbol{E}_{0}\right)$ responses of all footings at each site are similar, regardless of the footing width or depth; however, there is a distinct difference in the rate of stiffness degradation (reduction of $E_{s}^{\prime} / \boldsymbol{E}_{0}$ ) with increasing strain level between the sites. The rate at which stiffness degradation occurred (the degree of non-linearity) was highest at Shenton Park (site C), where $E_{\mathrm{s}}^{\prime} / \boldsymbol{E}_{0}=0.08$ at $s / B=1 \%$. This compares with $E_{\mathrm{s}}^{\prime} / \boldsymbol{E}_{0}$ values of $0 \cdot 2-0 \cdot 3$ at Texas (site A) and $0 \cdot 4-0.55$ at Blessington (site D), at the same normalised displacement.

Atkinson ${ }^{17}$ noted that the parameters that describe the nonlinear stiffness response of soils are the rigidity $\left(I_{R}\right)$, defined as the ratio of small-strain stiffness to strength $\left(I_{\mathrm{R}}=\boldsymbol{E}_{0} / \boldsymbol{q}_{\mathrm{ult}}\right)$, and the degree of non-linearity. He noted that the degree of nonlinearity decreases as $I_{R}$ reduces. Given that $\boldsymbol{q}_{\mathrm{c}}$ describes the soil strength at very large strain, and $\boldsymbol{E}_{0}$ was measured at the sites, the rigidity can be calculated as being in the range $I_{R}=$ 30-44 at site A, 10-12 at site D, and 46-59 at site C.

Consideration of Figure 8 a shows that the variation of rigidity suggests a plausible reason for the clear variation of the stiffness response evident at the three sites.

Further insight into the non-linear stiffness response can be obtained by considering the secant stiffness normalised by the CPT $\boldsymbol{q}_{\mathrm{c}}$ value $\left(\beta=E_{\mathrm{s}}^{\prime} / \boldsymbol{q}_{\mathrm{c}}\right)$ in Figure $8 \mathrm{~b}$. While there is a dearth of data at low normalised settlement $(s / B<0 \cdot 1 \%)$, the available data suggest that at a given site the initial $\beta$ value equals $I_{R}$. The $\beta$ values at all sites tend to converge as the normalised settlement increases, and are similar at all sites when $s / B$ exceeds $5 \%$. The convergence in the range of $\beta$ values with increasing $s / B$ is similar to that reported for the $\Gamma$ function in Figure 3. Given that the maximum allowable settlement beneath a shallow foundation is typically specified as $25 \mathrm{~mm}$, the resulting normalised settlement beneath a range of typical foundations of width ranging from $1 \mathrm{~m}$ to $10 \mathrm{~m}(s / B=0 \cdot 25-2 \cdot 5 \%)$ is shown in Figure $8 \mathrm{~b}$. It is clear that the spread of $\beta$ values recorded over this displacement range is quite significant $(\beta=2-24)$, which compares to the range of 1 to 3 typically used in design practice. ${ }^{16}$ While the data illustrate the difficulty associated with choosing a unique value of $\beta$ for use in settlement calculations, this does demonstrate that the range of $\beta$ values typically encountered when considering measured settlement data may be caused by variations in the sand rigidity and the normalised settlement level.

\section{DISCUSSION}

Comparison of the model and full-scale footing tests at large strains $(s / B>4 \%)$ suggests that a unique normalised pressuresettlement curve for footings in sand can be described (independent of the width and relative depth of the footing). However, the $\boldsymbol{q} / \boldsymbol{q}_{\mathrm{c}}$ ratio measured at low strain levels was not unique, and is affected by the geological formation and stress history of the sand deposit at the displacement levels of concern to footing designers $(s / B<2 \cdot 5 \%)$.

Gavin and Lehane ${ }^{23}$ presented a simple model that predicts the pressure-settlement curve for a pile in sand, with the shape of the curve depending on: (a) the sand state and pile type (i.e. displacement or non-displacement); (b) the previous loading 
history; and (c) the residual stresses at the pile base. Since residual stresses are not developed by shallow footings, a modified, two-stage form of the model is proposed (Figure 9), the key components of which are

(a) a linear stage (no stiffness degradation occurs) with the Young's modulus $\approx \boldsymbol{E}_{0}$, until a yield strain $\left(s_{\mathrm{y}} / B\right)$ is reached that, from Figure $8 \mathrm{a}$, can be assumed to be $0.03 \%$, and

(b) a parabolic (non-linear stage) up to a normalised base displacement level, $s / B=10 \%$.

The pressure mobilised during the linear stage can be obtained from

\begin{tabular}{|l|l|}
\hline 8 & $\boldsymbol{q}=k\left(\frac{s}{B}\right)$ \\
\hline
\end{tabular}

\begin{tabular}{|l|l|}
\hline 9 & $k=\frac{4 \boldsymbol{E}_{0}}{\pi\left(1-v^{2}\right)}$ for $s / B \leqslant s_{\mathrm{y}} / B$ \\
\hline
\end{tabular}

and during the parabolic stage from

$\quad \boldsymbol{q}=k\left(\frac{s_{\mathrm{y}}}{B}\right)^{1-n}\left(\frac{s}{B}\right)^{n}$
$\quad$ for $10 \%>s / B>s_{\mathrm{y}} / B$ and $s_{\mathrm{y}} / B \geqslant 0.03 \%$

The model can be used to predict the complete pressuresettlement curve for a footing up to $s / B=10 \%$. The input parameters required are the small-strain stiffness $\boldsymbol{E}_{0}$ and the bearing pressure at $s / B=10 \%$ (estimated using $\boldsymbol{q}_{0 \cdot 10}=0 \cdot 2 \boldsymbol{q}_{\mathrm{c}}$ ). The value of the exponent $n$ in Equation 10 is obtained by equating the bearing pressure prediction as $s / B=10 \%$ with the value derived from $\boldsymbol{q}=0 \cdot 2 \boldsymbol{q}_{\mathrm{c}}$. The creep effects can be accounted for by calculating $m$ coefficient values (given by Equation 7) from the initial normalised pressure-settlement curve derived using the model outlined above.

Figure 10 shows the first-time pressure-settlement response predicted using Equations 8, 9 and 10 for the test footings at Blessington and Texas (ignoring creep effects). The model provides a reasonable prediction of the measured response, and encouragingly seems to capture the effects of the footing width, embedment depth and sand state on the response over

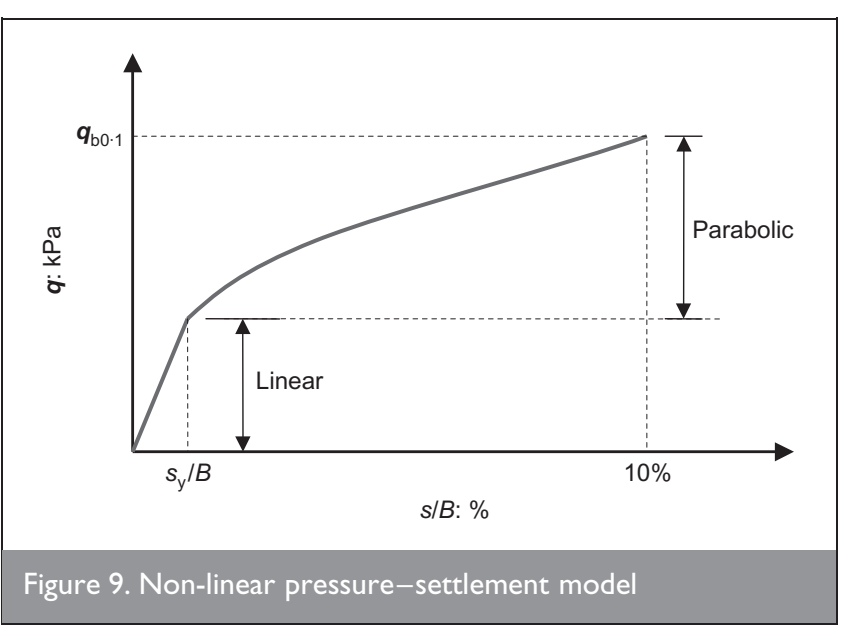

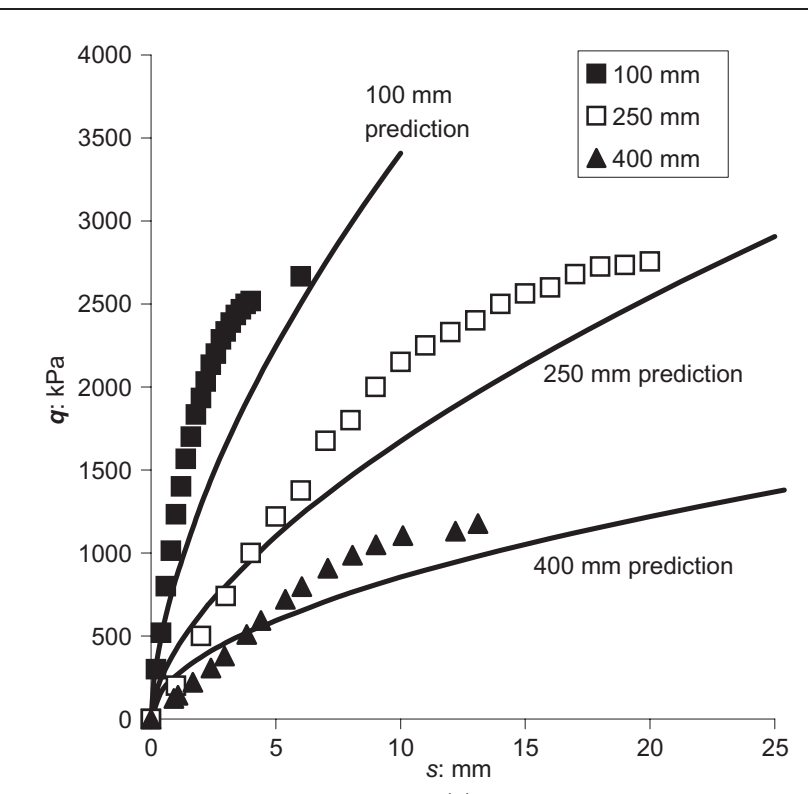

(a)

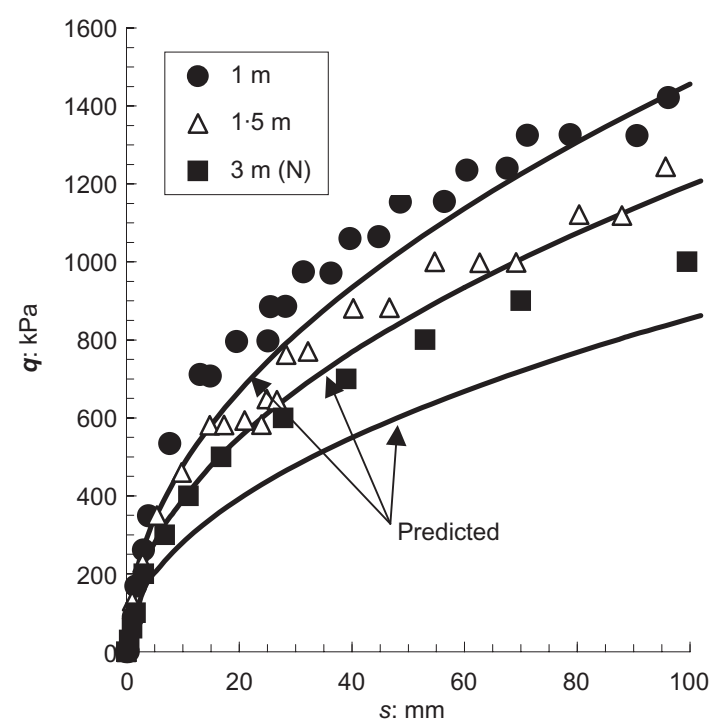

(b)

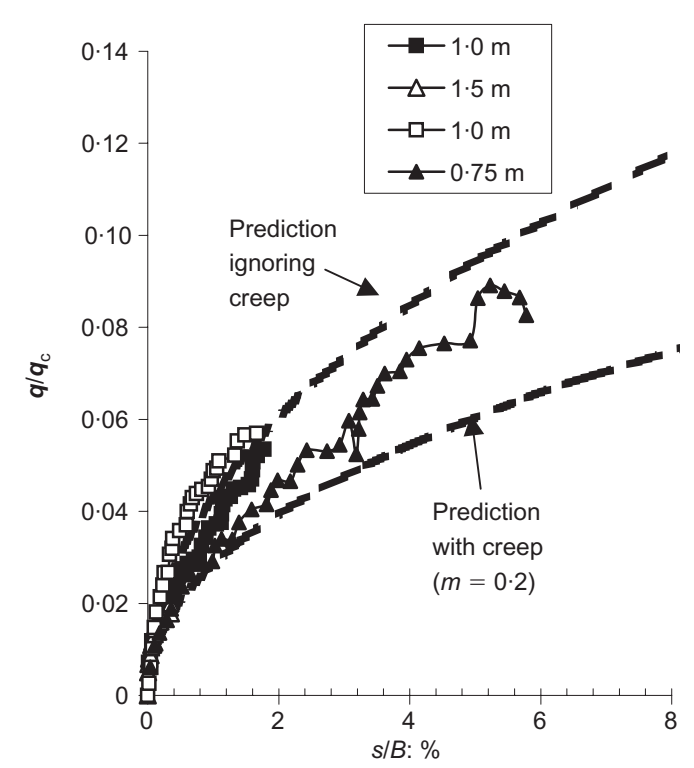

(c)

Figure 10. Prediction of pressure-settlement response of footings using model: (a) Blessington, Site D; (b) Texas, Site A; (c) Shenton Park, Site C 
the full strain range. The significance of the creep effect at Shenton Park is shown in Figure 10c. When the effects were not considered in the model, the settlement response was clearly underpredicted. A significant improvement in the prediction was achieved by including creep effects.

\section{SUMMARY AND CONCLUSIONS}

Plate load tests performed at a very dense sand test site were compared with full-scale load tests performed at a range of sites, and suggest that the normalised bearing resistance mobilised at relatively large settlements $(s / B>5 \%)$ is independent of the footing width and embedment depth. While recognising that the bearing resistance continues to increase with settlement until failure occurs, and that creep effects may significantly influence the response, it appears that the bearing resistance values $\boldsymbol{q}_{0.05}$ and $\boldsymbol{q}_{0.10}$ mobilised at $s / B=5 \%$ and $10 \%$ respectively can be adequately predicted simply as welldefined fractions of the cone penetration test $\boldsymbol{q}_{\mathrm{c}}$ value.

At $s / B<5 \%$ the normalised bearing resistance $\left(\boldsymbol{q} / \boldsymbol{q}_{\mathrm{c}}\right)$ mobilised was affected by the geological formation and stress history of the deposit. During first-time loading of footings the stiffness response is controlled by the rigidity of the soil. Sands with high rigidity exhibit strong stiffness non-linearity. This results in rapid development of their available bearing resistance. In contrast, the available resistance of sand with low rigidity mobilises more gradually. This effect is illustrated in Figure 11, which shows predictions of the bearing pressure mobilised at a footing settlement of $25 \mathrm{~mm}\left(\boldsymbol{q}_{0.025}\right)$ as a function of the CPT $\boldsymbol{q}_{\mathrm{c}}$ resistance, $I_{\mathrm{R}}$, and the footing width.

A simple pressure-settlement model was proposed and proven to provide reasonable estimates of the measured response for both model and full-scale footings. In particular, the model captured the main features that control the rate of mobilisation

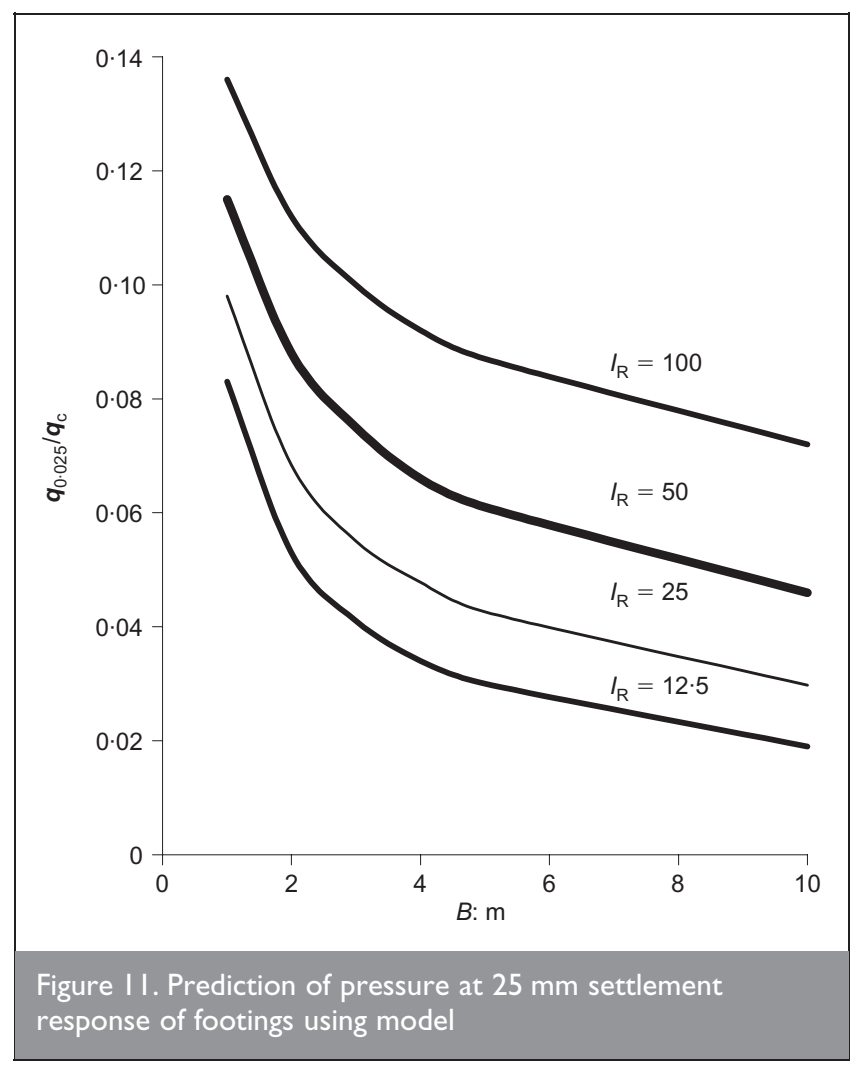

of the footing resistance, namely footing width, sand state and rigidity. Given the lack of scale effects evident in the footing tests when normalised in an appropriate manner, it appears that the input parameters for the model, such as the initial stiffness and the creep coefficient, can be obtained from relatively low-cost in situ shear wave modulus and plate loading tests.

\section{ACKNOWLEDGEMENTS}

This work was part of a research project sponsored by Sustainable Energy Ireland and Aertech Ltd. The authors would like to thank Professor Barry Lehane for helpful comments on the original draft, the technical staff in the civil engineering departments at Trinity College Dublin and University College Dublin, and Roadstone Ltd for unhindered access to the Blessington site. The paper was written by the lead author while working as a research associate in the Urban Institute, University College Dublin. Financial assistance provided by the Urban Institute is gratefully acknowledged.

\section{REFERENCES}

1. RANDOLPH M. F., JAMIOLKOWSKI M. B. and ZDRAVKOVIC L. Load carrying capacity of foundations. Proceedings of Advances in Geotechnical Engineering: The Skempton Conference, London, 2004, 1, 207-241.

2. Altae A. and Fellinius B. H. Physical modelling in sand. Canadian Geotechnical Journal, 1994, 31, No. 3, 420-431.

3. OVESEN, N. K. The scaling law relationships. Proceedings of the 7th European Conference on Soil Mechanics and Foundation Engineering, Brighton, 1979, 319-323.

4. Cerato A. B. and Lutenegger A. J. Scale effects of shallow bearing capacity on granular material. ASCE Journal of Geotechnical and Geoenvironmental Engineering, 2007, 133, No. 10, 1192-1202.

5. YAmamoto N., RANDolPh M. F. and EinAV I. Numerical study of the effect of foundation size for a wide range of sands. ASCE Journal of Geotechnical and Geoenvironmental Engineering, 2008, 135, No. 1, 37-45.

6. White D. J., The K. L., Leung C. F. and Chow Y. K. A comparison of the bearing capacity of flat and conical circular foundations on sand. Géotechnique, 2008, 58, No. 10, 781-792.

7. ZHU F., CLARK J. I. and PhILLIPS R. Scale effect of strip and circular footings resting on a dense sand. ASCE Journal of Geotechnical and Geoenvironmental Engineering, 2001, 127, No. 7, 613-621.

8. BRIAUD J. L. Spread footings in sand: load settlement curve approach. ASCE Journal of Geotechnical and Geoenvironmental Engineering, 2007, 133, No. 8, 905-920.

9. ISMAEL N. F. Allowable pressure from loading tests on Kuwaiti soils. Canadian Geotechnical Journal, 1985, 22, No. 2, $151-157$.

10. Terzaghi K. and Peck R. Soil Mechanics in Engineering Practice, 2nd edn. Wiley, New York, 1967.

11. Burland J. B. and Burbridge M. C. Settlement of foundations on sand and gravel. Proceedings of the Institution of Civil Engineers, Part 1, 1985, 78, No. 6, 1325-1381.

12. ESLAAMIZAAD S. and RoBertSon P. K. Cone penetration testing tests to evaluate bearing capacity of foundations in sands. Proceedings of the 49th Conference of the Canadian Geotechnical Society, 1986, 429-438. 
13. LEE J. and SALGADO R. Estimation of bearing capacity of circular footings on sands based on cone penetration test. ASCE Journal of Geotechnical and Geoenvironmental Engineering, 2005, 131, No. 4, 442-451.

14. De Cock F., Legrand C. and Huybrechts N. Overview of design methods of axially loaded piles in Europe: report of ERTC3-Piles, ISSMGE Subcommittee. Proceedings of the 8th European Conference on Soil Mechanics and Geotechnical Engineering, Prague, 2003, 663-715.

15. Cadogan D. D. and Gavin K. G. Examination of scale effects during field tests on model bored piles in overconsolidated sand. Proceedings of the International Conference on Physical Modelling in Geotechnical Engineering, Hong Kong, 2006, Vol. 2, pp. 1335-1342.

16. DAS B. M. Advanced Soil Mechanics. McGraw-Hill, New York, 1983.

17. ATKINSON J. Non-linear soil stiffness in routine design. Géotechnique, 2000, 50, No. 5, 487-508.

18. Lehane B. M., Doherty J. P. and Schneider J. A. Settlement prediction for footings on sand. Keynote lecture. Proceedings of the Conference on Small-strain Stiffness in Practice, Atlanta, 2008, 133-150.

19. BRIAUD J.-L. and GibBEnS R. M. Large-scale Load Tests and Database of Spread Footings on Sand. Federal Highway Administration, 1997, publication No. FHWARD-97-068.

20. GaVin K. G. and O'Kelly B. C. Effect of friction fatigue on piles in dense sand. ASCE Journal of Geotechnical and Geoenvironmental Engineering, 133, No. 1, 63-71.

21. Kulhawy F. H. and Mayne P. W. Manual on Estimating Soil Properties for Foundation Design. Electric Power Research Institute, Palo Alto, 1990, Report EL-6800.

22. Papadopulous B. P. Settlement of shallow foundations on cohesionless soils. ASCE Journal of Geotechnical Engineering, 1992, 118, No. 3, 377-393.

23. GAVIN K. G. and LEHANE B. M. Base load-displacement response of piles in sand. Canadian Geotechnical Journal, 2007, 44, No. 9, 1019-1052.

\section{What do you think?}

To comment on this paper, please email up to 500 words to the editor at journals@ice.org.uk

Proceedings journals rely entirely on contributions sent in by civil engineers and related professionals, academics and students. Papers should be 2000-5000 words long, with adequate illustrations and references. Please visit www.thomastelford.com/journals for author guidelines and further details. 